\title{
Using WhatsApp to Create a Space of Language and Content for Students of International Relations
}

Uso de WhatsApp para crear un espacio de lenguaje

y contenido para estudiantes de Relaciones Internacionales

Uso do WhatsApp para criar um espaço de linguagem e conteúdo para estudantes de Relações Internacionais

Conor KEOGH

Universidad del Norte, Barranquilla, Colombia Corresponding author: ckeogh@uninorte.edu.co Orcid: http://orcid.org/o000-0003-I529-679I

Received: 2017-02-15

Accepted by peers: 2017-05-09
Send to for peer review: 2017-03-15

Approved: 2017-06-16

To reference this article in APA style / Para citar este artículo en APA / Para citar este artigo Keogh, C. (2017). Using WhatsApp to create a space of language and content for students of international relations. Latin American Journal of Content and Language Integrated Learning, 10(1), 75-104. doi:10.5294/laclil.2017.10.1.4 
ABSTRACT. For language learners of this generation, the smart phone represents a key cultural artefact that complements the learning process. Instant messaging applications such as WhatsApp are widely used in personal, professional and, increasingly, academic circles to maintain constant contact among friends, colleagues, or classmates. This study seeks to analyze how a group of 19 International Relations students and their teacher utilized a WhatsApp chat group throughout their semester-long English class. The group was conceived of as being an extension to a Community of Practice. On a basic level, the chat group was to be used as a shared space in which learners could practice their use of new phrases or vocabulary learned within the class in relation to real life issues connected to themes associated with International Relations. The space could also be interpreted as a virtual ZPD (Zone of Proximal Development) in which learners were scaffolded by their teacher as well as their classmates. Finally, the group provided a space in which learners could engage dialogically and more openly in a truly collective, reciprocal, supportive, cumulative, and purposeful manner. This qualitative study analyzed both interactions within the group and student reflections on its effectiveness, which served to indicate that such a group space can lead to effective learner scaffolding, increased learner participation, and the formation of an advantageous community of learners.

Keywords: CLIL; Scaffolding; WhatsApp; Community of Learners; International Relations.

RESUMEN. Para la generación actual, el teléfono inteligente representa un elemento cultural que complementa el proceso de aprendizaje. Los mensajes instantáneos de la aplicación de WhatsApp se usan masivamente en círculos sociales, profesionales, y su uso ha crecido en círculos académicos con el fin de mantener contacto permanente entre amigos, colegas o compañeros de clase. Este estudio busca analizar cómo Ig estudiantes de Relaciones Internacionales y sus profesores utilizaron un grupo de chat de WhatsApp durante un semestre en clase de inglés. El grupo se concibió como una extensión de una comunidad de práctica. Básicamente, el grupo de chat se usó como un espacio compartido para que los estudiantes practicaran el uso de vocabulario nuevo aprendido en clase de inglés, acerca de eventos de la cotidianidad en temas asociados a relaciones internacionales. La práctica también se interpretó como zona de desarrollo próximo (ZPD-Zone of Proximal Development) por medio de la cual los estudiantes recibieron apoyo del profesor y de sus compañeros. Finalmente, el grupo de chat proporcionó un espacio para que los estudiantes pudieran relacionarse dialógicamente y de una forma más abiertamente colectiva, recíproca, enfocada y apoyada mutuamente. Este estudio cualitativo analizó en su efectividad las interacciones de parte y parte al interior de las reflexiones de los estudiantes, lo cual sirvió para indicar que este espacio grupal puede conducir a un apoyo de aprendizaje efectivo, incrementar la participación del estudiante y formar una provechosa comunidad de estudiantes.

Palabras clave: AICL; andamiaje; WhatsApp; comunidad de aprendices; Relaciones Internacionales.

Resumo. Para a geração atual, o telefone inteligente representa um elemento cultural que complementa o processo de aprendizagem. As mensagens instantâneas do aplicativo WhatsApp são usadas em massa em círculos sociais, profissionais, e seu uso tem crescido em círculos acadêmicos com o fim de manter contato permanente entre amigos, colegas ou colegas de turma. Este estudo procura analisar como Ig estudantes de Relações Internacionais e seus professores utilizaram um grupo de chat de WhatsApp durante um semestre na aula de inglês. O grupo concebeu-se como uma extensão de uma comunidade de prática. Basicamente, o grupo de chat foi usado como um espaço compartilhado para que os estudantes praticassem o uso de vocabulário novo aprendido na aula de inglês, acerca de eventos da cotidianidade em temas associados a relações internacionais. A prática também se interpretou como Zona de Desenvolvimento Proximal (ZDP; em inglês Zone of Proximal Development, ZPD) por meio da qual os estudantes receberam apoio do professor e de seus colegas. Finalmente, o grupo de chat proporcionou um espaço para que os estudantes pudessem se relacionar dialogicamente e de uma forma mais abertamente coletiva, recíproca, focada e apoiada mutuamente. Este estudo qualitativo analisou em sua efetividade as interações de ambas as partes ao interior das reflexões dos estudantes, o qual serviu para indicar que esse espaço de grupo pode conduzir a um apoio de aprendizagem efetiva, aumentar a participação do estudante e formar uma proveitosa comunidade de estudantes.

Palavras-chave:AICL; andaime(Scaffolding);comunidadedeaprendizes; Relações Internacionais;WhatsApp. 


\section{Introduction}

Learning English in a country that does not speak the language has always been a challenge. This is the environment that the author has been working in for the past six years as an English language teacher working in Colombia. Colombia, like much of the world, has seen an increased clamour for the acquisition of English as the country strives to boast a bilingual population. The disadvantage of learning English outside of a country where it is spoken as a first language has been eased somewhat by the technological advances that have seen the world become a globalised community in the past twenty years. Learners now have access to a wide array of options to aid in their learning and practice of the language. One such aid is smart phone technology, which offers a diverse range of methods of communication such as instant messaging services like the WhatsApp application. This however, represents a great advantage to the learners of this generation, as whereas in the past the cultural artefacts (Motterman \& Sharma, 2009, p85) of learning such as books and journals were only available to those fortunate enough to study in certain institutes or those capable of buying them, the modern artefacts such as smart-phones are becoming common place even for those of lower economic means. Through the easy access to information offered by the global community which the internet has created and the new connections made possible by social networks or applications such as WhatsApp, learners in this age are more privileged than perhaps ever before to acquire valuable knowledge on areas of immediate interest and forge new identities in a world which can be held in the palm of their hand. A world, which can be visited at any minute and at almost any location. What this means is that for learners of this net-generation, the lines are increasingly blurred between the areas of work and play (Coffin, 2009). Furthermore, this blurring of the boundaries offered by instant messaging services such as WhatsApp is allowing added exposure to target languages (Almekhlafy \& Alzubi, 20I6). This research was conducted at a university in the north of Colombia. The author has been living and working in Colombia for six years and has witnessed firsthand the desire and in many cases, the necessity of the academic and professional population 
to acquire or improve their proficiency in the English language. This in itself should come as no surprise seeing as the benefits of a global language are "...particularly appreciated by the international academic and business communities" (Crystal, 2003, p57). There exists in Colombia a high level of professional competitiveness and the acquirement of proficient English is in demand. A certain level of competitiveness also exists between the major cities in the country, and the city where the research was conducted has been credited by the government as being a pioneering city in its efforts to implement a policy of bilingualism in its education system.

The university in question has been central to this development plan through its academic department and training courses that it operates for public school teachers throughout region. Within the university, classes are offered to both undergraduate and postgraduate students as well as employees and members of the public. The focus of this study was a level 6 class of International Relations English consisting of I8 undergraduate students between the ages of I8 and 2I. The students are expected to possess a B2 level of English according to the Common European Framework. There are eight levels in the International Relations English program and the expectation is that students who enter at level one should possess an A2 level according to the CEFR and those who complete all levels should leave at a high B2 level. The first four levels of the program are primarily concerned with fortifying the general English abilities of the students while simultaneously covering topics of interest to the student's degree (geography, history, environmental issues). Levels 5-8 however, are much more content focused with a greater emphasis on learning through English. Students who test into the program at a high BI level are permitted to enter the program at level five. This means that the students who form the classes from levels 5-8 may be at different levels of progress in terms of working towards their degrees. The core focus of level six is on intercultural communication between people, groups, states and blocks. Students explore how communication takes place as well as examining the myriad of ways in which miscommunication could occur, and subsequently apply these concepts to various case studies related to the world of International Relations. The course study guide was produced 
by the International Relations English department and contains key content related to the language and content goals of the course.

It was established at the beginning of the course that all of the learners possessed smart phones and regularly used the WhatsApp application. There was an immediate enthusiasm for the creation of a class group using the technology and the group was active within the first few days of the semester. It was obvious from the offset that this group were eager to embrace "...the blurriness about where people learn, and how and where they learn most effectively" (Coffin, 2009, p5I5). All of the learners later agreed to the use of the class group in this study.

The focus of this study was to explore how the WhatsApp instant messaging service could be of use to learners of English from an undergraduate degree on International Relations in a university in the north of Colombia. The aim of this research was to explore how learners adapt to this additional space. In particular, the following research questions were considered:

"Does the use of the group lead to increased learner participation?

»What types of interaction occur in this space?

" Can the group space be used for effective scaffolding of learners?

"Would the group show signs of forming a community of learners around shared themes?

»What are the learner's perceptions of using the technology?

\section{Methods}

The increased use of handheld technology is simply a fact of modern society. An attempt at reversing this trend is perhaps impossible whereas a failure to utilize such a trend for the benefit of second language acquisition would be at best shortsighted. It was felt that the incorporation of the WhatsApp application in the form of a class group consisting of all the students and the teacher could provide learners with a supportive platform, an additional space where they can learn language, learn about language and learn through language. The group space was perceived as being an ideal site in which the four C's; content, 
communication, cognition and culture (Coyle, Hood \& Marsh, 20Io); would combine to assist and enrich the experience of the learners.

This virtual space of the class group is being viewed here as a component of the Zone of Proximal Development (ZPD) as proposed by Lev Vygotsky (1978). This concept has been of great importance to applied linguistics and particularly socio-cultural theory. Vygotsky (I978, p53) defined the zPD as being “...the distance between the actual development as determined by independent problem solving and the level of potential development as determined by problem solving under adult guidance or in collaboration with more capable peers". Seen from this perspective, the class group was intended as a tool through which the learners could strive to enhance their actual development (current level of proficiency) through interactions with the teacher and their own classmates. The hope was that through viewing, erring, experimenting and participating, learners would benefit on the premise that what they can do with assistance today, they can do alone tomorrow (Vygotsky, I978).

One of the things that was expected to be observed were examples of scaffolding. This refers to one of the ways learners develop within the ZPD, a process through which "...the more capable members share responsibility with the less capable members in the doing of an act, gradually letting them assume greater responsibility" (Hall, 20I2, p49). Therefore, the idea of scaffolding in relation to a CLIL learning environment is perceived here as being concerned with how a teacher or a more capable classmate within the group supports and aids a learner or less capable speaker become more competent with aspects of grammatical structure or vocabulary related to the International Relations focus as well as broadening the knowledge base on course content, and strengthening skills (discussion, presenting opinions, dialogue) necessary for a career in this field. For many the concept of scaffolding remains at “... an abstract level..." (Maybin et al, I992, pI87), so it is important to note here that it is being interpreted as instances where learners enhance an aspect of their knowledge of the language or course content, or benefit from their interactions with both their teacher and fellow learners within the space of the WhatsApp group. This might be when the teacher or learners explicitly assist with a language, content based problem, or perhaps when learners themselves 
register and improve upon an aspect of their communication through observing the dialogue within the group.

As mentioned above, this group space needs to be viewed as a cultural artefact (Motterman \& Sharma, 2009), a tool to be used in a specific action as books and pencils were utilized by previous generations. Indeed, this new technology offers the possibility of "...a significant impact on the learning process..." (Motterman \& Sharma, 2009, p86). It must not be forgotten however, that language is also a cultural artefact, one which is "...pervasive and powerful..." and allows humans to make sense of their connection to each other and the world (Lantolf \& Thorne, 2006, p20I). Here the implementation of the class group was intended as a space where learners could use this most precious of cultural artefacts, the ability of language use for true interaction. It was hoped that this artefact would offer learners a space where they would learn and improve language skills and examine language. Furthermore, the group would have the potential to achieve goals and use the language as a vehicle to explore themes and topics of immediate interest to students of International Relations. In terms of language learning, it was expected that the group would be the site of one particularly narrow kind of scaffold (Forman, 2008, p323) in the form of traditional Initiation-Response-Evaluation (IRE) interactions between teacher and students, whereby the learners respond to a question or instruction from the teacher and are then provided with an evaluation, perhaps in the form of a correction. This was because one use of the group was as a shared homework journal and it was expected to be used for explicit corrections that would provide clear feedback to all members of the group. It was further hoped that the group would provide various examples of Initiation-Response-Follow up (IRF) interactions where instead of being merely corrected, learners would be encouraged to elaborate on their response and in the process help establish "...an inclusive intellectually rich classroom community..." (Hall, 20I2, p95) communicating in English in discourse of immense relevance in the world of international affairs within the virtual and interactive space that is the WhatsApp group. Interactions between learners would enable them to enhance their abilities such as offering and defending an opinion or debating skills, enabling learners to understand more about how language works. Discussion and debate provide favorable conditions for 
establishing a healthy amount of intersubjectivity between members of the group, seen as crucial in the "... co-construction of curricular knowledge" (Dalton-Puffer, 2007, p75). The use of language as a vehicle for learning. Learning through language.

While some structured interactions were expected from the group, the space itself was not implemented with the idea of being a teacher-dominated area. The group was conceived as being an extension to a Community of Practice (Lave \& Wenger, I99I), communities which consist of groups of people who "...share a concern, a set of problems, or a passion about a topic, and who deepen their knowledge and expertise in this area by interacting on an ongoing basis" (Wenger et al, 2002, p7). It was hoped that the group would help foster a sense of solidarity and support among the students, and offer a space where meaningful dialogue may occur, features that have been suggested as strengths of messaging services such as WhatsApp (Bouhnik \& Deshen, 20I4). It was emphasized from the offset, that the group was to be the shared responsibility of all its members and learners were encouraged to take the initiative whenever possible. It was through this emphasis on shared importance and responsibility that I hoped to see examples of true dialoguing whereby learners would interact more openly in a truly collective, reciprocal, supportive, cumulative and purposeful manner (Alexander, 2008, p. II3), and in the process assist one another in the generation of knowledge.

The creation of the class group was also influenced by the concept of the Third Space (Gutierrez, I995/2008). Gutierrez saw this concept as being a "...transformative space where the potential for an expanded form of learning and the development for new knowledge are heightened" (Gutierrez, 2008, p.I52). What was particularly pertinent for this research project was the opportunity the space would provide to assist in the learners' vertical (knowledge built in class such as grammar, vocabulary and cases and concepts related to course content) and horizontal (knowledge gained from participation and interaction) learning. Viewing the group as a shared third space of this community of practice also raised the possibility of having an additional space or dimension where learner identity and participation could perhaps evolve alternatively to the forms encountered within the classroom. The concepts of participation and identity have come to be seen as 
crucial within the socio-cultural perspective on language learning (Morita, 2004; Norton, 2000), and with the opportunities for the forging of new identities offered by such modern cultural artefacts, learner perception of this new space was also of the utmost importance

The redesign was focused on the integration of the WhatsApp instant messaging application as a core component in a level 6 course of International Relations English. All of the students involved in the class possessed the necessary technology (a smart phone with internet access) and agreed to the formation of a class group conversational space (an open space of continuous dialogue involving all the students in the class). Within this space, all group members had the capacity to post comments or messages in typed or spoken form. It was also possible for them to include images or links to other forms of media. This virtual space created by the implementation of the WhatsApp group allowed a stream of interaction among the group. It was used on one level as a shared online homework journal. While the learners were still required to complete certain tasks within their textbook or write longer texts in a notebook, the WhatsApp group became the space where new vocabulary or grammar, which was covered in class, was utilized by learners. This consisted mainly of learners being instructed to include the new word, phrase or grammatical structure within a post in the group.

Furthermore, it was used as a space in which concepts related to the course content could be discussed by all the members for the space had been envisaged as being an additional space to help this particular community of practice. Here the learners use English as the vehicle through which to explore their field of interest and build knowledge through meaningful interaction. The implementation was intended as creating a space where the learners could seize the initiative, demonstrate their capability and gain true experience of interacting in English on topics of immediate interest.

In terms of analysis, this research was primarily concerned with qualitative methods, principally an analysis of the interaction within the group to identify the ways in which the space supported and encouraged learner interaction, and listening to whether the learners themselves perceived the group space as being advantageous or beneficial. The WhatsApp group proved to be an extremely practical tool. As mentioned above, all the learners were already familiar with the 
use of this service and so its implementation was a smooth transition for all. The group was created and within minutes, dialogues had been initiated. All of the utterances, interactions and assignments throughout the semester were stored on all of the phones and when the time came to analyze its various uses, pertinent or relevant examples were selected. In particular, instances that were seen as examples of scaffolding were identified and their significance explored. Furthermore, evidence that the group was showing signs of being a community of practice was compiled and organized into suitable thematic groups. However, the opinions of the learners involved were also of immense importance to the study. For this reason, at the end of the course all of the learners were asked to post in the group reflecting on their experience using the application and five of the learners also volunteered for a semi-structured interview in order to allow a further exploration of their opinions on the use of the WhatsApp group. This would provide further support for the significance of the interaction found within the group from the perspective of those learners of whom it was comprised. The interviews were recorded and their content transcribed. The transcriptions were then analyzed and grouped appropriately within the dominant themes that emerged.

\section{Results}

As noted in the previous section, the data generated by this investigation consisted of contributions to the WhatsApp group (four months of tasks and interactions), reflections on the usefulness of the group (posted in the group at the end of the semester) and face-to-face interviews with five of the learners. The interviews focused on how learners participated in the group, when and where they used it, how they felt it was different from a traditional class and what they felt were its greatest strengths. It was felt that this data would offer an abundance of material, which would allow the research questions to be addressed. In this section, the focus will be on three of the dominant themes of the research: the group as a collective ZPD and site of 
learner scaffolding; the group as a community of practice and site of learner interaction, learner reflection on the redesign.

\section{The Group as a Collective ZPD and Site of Learner Scaffolding}

Within the group, there were various examples of IRE interactions.

These generally began with a teacher led initiation requesting the learners to post messages using features of language, which had been covered within the classroom, and the teacher responded to these postings. One such example can be seen in an interaction where several learners were posting examples using reported speech of questions they had been asked by fellow students within the class and posting their responses (Figure A). The postings by the students were overall structurally sound and therefore the students were offered feedback by the use of the thumbs up emoticon in the app. In the three instances where the learners' contributions included minor structural errors, explicit correction was offered using an asterisk to highlight this as being a very narrow scaffold, or the evaluation part of an IRE interaction. Such immediate corrective feedback, despite being narrow in its scope, was mentioned by learners as being a positive aspect of their experience with the group space.

Another instance from the group (Figure B) highlights the potential of the group space for learner-learner scaffolding whereby two of the learners actively co-construct meaning in response to the teacher stating that he was "knackered". One of the learners (Mariana) inquired as to the meaning of this term and another (Maria Paula) surmised from the context that it meant tired.

Instances of content-knowledge scaffolding can also be found among the data (Figure C). In the third week of semester, the group was discussing and sharing their understanding of barriers to communication by providing examples.

Once more, narrow feedback is provided in the form of the thumbs up emoticon, but when one of the learners (Stefania) enquires as to whether religion could be viewed as a barrier, the teacher is able to respond with a concise but detailed response explaining how religion could be connected to the barriers of prejudice or ethnocentrism (two ideas covered within the classroom) in certain cases. Here perhaps, 
Figure A. Narrow scaffolding within group

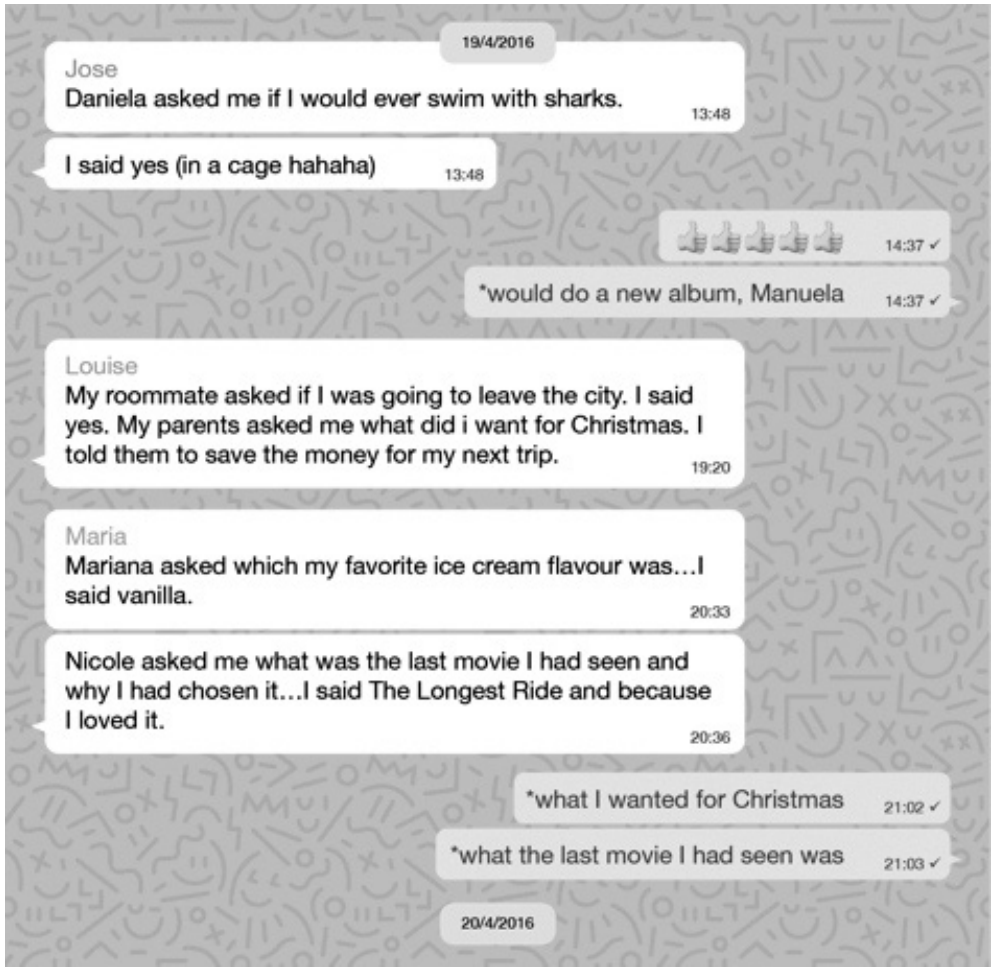

Figure B. Learner-learner Scaffolding Co-construction of knowledge

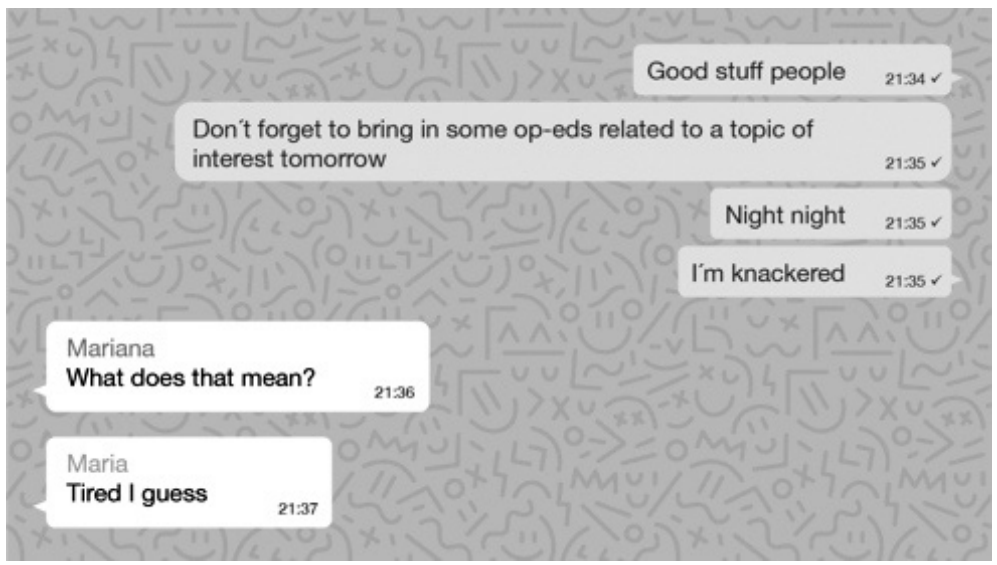


Figure C. Scaffolding of course content (1)

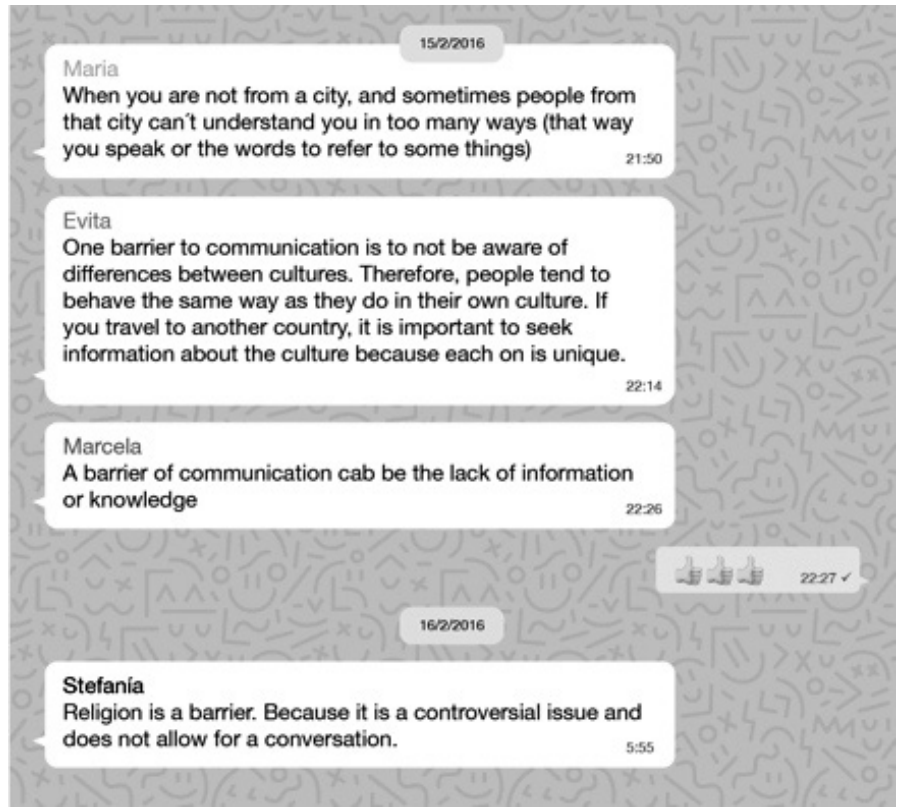

One barrier to communication is to not be aware of differences between cultures. Therefore, people tend to behave the same way as they do in their own culture. If you travel to another country, it is important to seek information about the culture because each on is unique.

Marcela

A barrier of communication cab be the lack of information

or knowledge

Figure C. Scaffolding of course content (2)

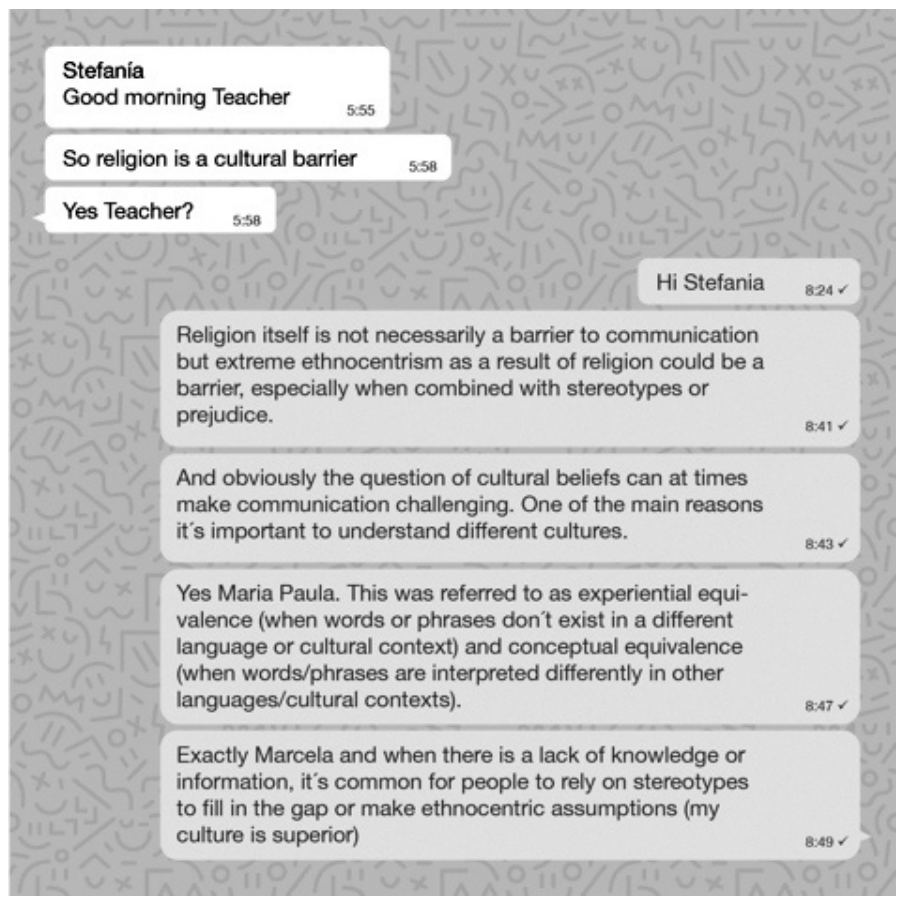


one can appreciate the benefits of such an application for expanding the opportunities for the provision of necessary scaffolding and learner support beyond the four walls of the classroom. Content knowledge was further scaffolded through the sharing of information on the topic of the Balkan conflict in the mid-I9gos. The case had proved difficult for the students to comprehend within the classroom due to the historical and ethnic complexities at its core. The group provided an extended space where learners could post what they had read about a certain aspect of the conflict and share this information to assist in the co-construction of content knowledge (Figure D).

Figure D. Scaffolding through shared knowledge (1)

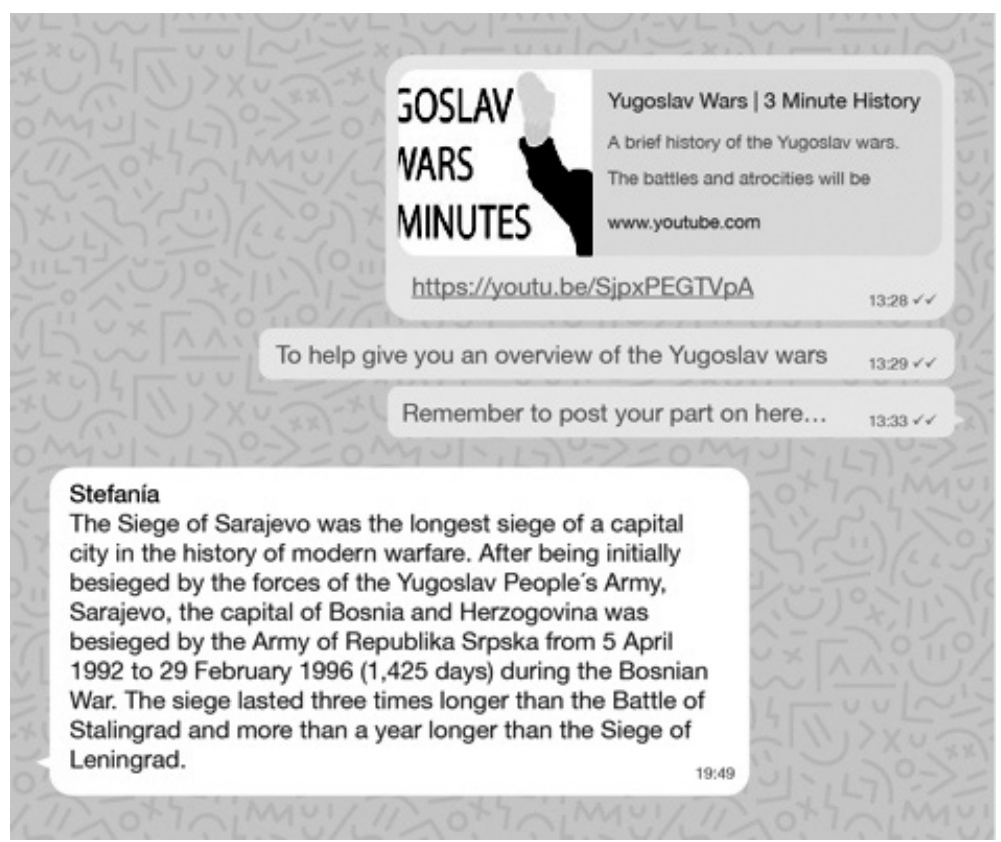

Stefania

The Siege of Sarajevo was the longest siege of a capita People's Army. Sarajevo, the capital of Bosnia and Herzogovina was besieged by the Army of Republika Srpska from 5 Apri 1992 to 29 February 1996 (1,425 days) during the Bosnian War. The siege lasted three times longer than the Battle of Stalingrad and more than a year longer than the Siege of Leningrad. 
Figure D. Scaffolding through shared knowledge (2)

Mariana
What does Siege means?

20:01

Mean*

And what was the reading? Is it in the catalogue or email?

Alexandra

The Republika Srspka is a constituent part of Bosnia and Herzogovina, an internationally recognized state. While the Republika Srspka is not recognized as an independent state by any other state, some Republika Srpska officials at the highest levels dispute and question the existence of the state of Bosnia and Herzogovina, and have predicted and advocated for the states dissolution, and challenged the functionality of the state and its responsibilities under the Constitution of Bosnia and Herzogovina.

20:06

Republika Srspka leaders continue to challenge the Dayton Agreement with rhethoric that advocates Republika Srspka independence.

Mariana

Richard Holbrooke was an American diplomat whose contributions were crucial for the resolution of the Bosnian War. $\mathrm{He}$ was able to convene with Bosnian warring factions to negotiate the signing of the Dayton Peace Accords, that brought peace to Bosnia in 1995. He was also the leader of the negotiation team charged to resolve the Balkan crisis.

It must be noted that all of the activities and interactions, which have been referred to above, would not seem out of place within a traditional classroom environment. The advantage offered by the WhatsApp group space however, is that such activities and interactions were made outside the limited hours provided in the classroom, and that the scaffolding was also available not only to those learners actively involved in the interaction, but also to those who were reading. This is a point, which will be returned to in the analysis of the learner perceptions. 


\section{The Group as a Community of Practice and Site of Learner Interaction}

Within the posts in the group, there was ample evidence that it was serving as an effective community of practice. To demonstrate this, it is worth looking at four examples from the postings. One such instance (Figure E) was initiated by the posting of a newspaper article criticizing the use of the word "jungle" by the media when referring to a refugee camp in France. Previously the group had discussed the language of othering within the classroom as a key concept of course content. This article offered an up to date prompt for the learners to further explore the theme. Despite only two of the learners responding to the prompt, the opinions were very well developed and used the article to build upon what they had discussed. Again, it is important to reiterate the potential value of such discussions and interactions for silent readers of the group space.

Another intriguing interaction within the group stemmed from an activity where learners had been asked to post examples using key course vocabulary that had been discussed within the classroom. The key part of the interaction (Figure F) was when Jose utilised the adjective "ambiguous" by commenting on a current affairs issue involving the police in Colombia.

The teacher was able to use this issue by steering the learners towards a discussion on the intricacies of the case that involved questions over journalistic integrity. Here one can see how the careful use of the follow-up question within an IRF structure can open up new spaces and opportunities for learners. Such improvisation could be viewed as an example of "rhyzomatic learning" (Leander \& Wells Rowe, 2006), whereby the focus of an activity is shifted by the contribution of the teacher or learner, and new possibilities for learning are presented. Further discussions on topics such as post-conflict reconciliation add credence to the claim that the group was showing strong evidence of a being a community of practice. These discussions were continuations of themes and activities that had been the focus in earlier classroom tasks. In one passage (Figure G), group members have posted responses to questions posed by the teacher in relation to a series of short readings and videos on the reconciliation process in Rwanda. 
"Stop calling the Calais refugee camp the jungle" | Joseph Harker http:/gu.com/p/4hb5n/swa

Mariana

That is another example of othering...lis time for governments to stop this and make adjustments to their language so we can all start tolerating others and stop legitimizing some group's exclusion.

Do we think these examples of othering are intentional or unintentional?

Do people use these phrases conscioushy, or not?

By people, I mean the media btw.

Mariana

I think that the use of terms ike those (the jungle) to refer to a group of people is completely intentionat they do it as a sign of disapprovement and it encourages other people's intolerant behaviors and opinions towards them.

It's ok to nun into a jungle and destroy some "savages" houses, but it would not have that degree of acceptance if it weren t for thcse terms no one (I believe) will agree to destroy the house of someone just because.

That kind of information given obeys to political interests that some newspapers and magazines because of their owners and their personal and political interests.

\section{Marcela}

I think to change the idea of people on refugees depends not only on governments. As the text says, clearly it is a matter of humanization. Of course governments and media sell us ideas easily bought. But the attitude that we face circumstances are what define us as people and give us our humanity. These types of comments teaches us that we are a world full of hypocrites, we often criticize issues such as the Israeli-Palestinian conflict, it has been in history a negative view of the behaviour of people like Hitler, Mussolini, Stalin, but really are we so different from them? The nationalism of many people right now is as strong as theirs. And we already know the result of such fervent ideology... 
Figure F. Discussion of local context: Rhyzomatic learning (1)

Mariana

My boyfriend arrived to Barranquilla yesterday to surprise

me, so I am still in awe.

$15: 43$

Jeffres

I'm going to leave the group soon, my phone is a kind of

broken, it wasn't necessary to specify but I wanted to

avoid the uncertain.

$15: 45$

Jose

Has anyone read about La comunidad del anillo? I think there's still a certain ambiguity about what really happened

between those officers hahahahahah

15:59

Figure F. Discussion of local context: Rhyzomatic learning (2)

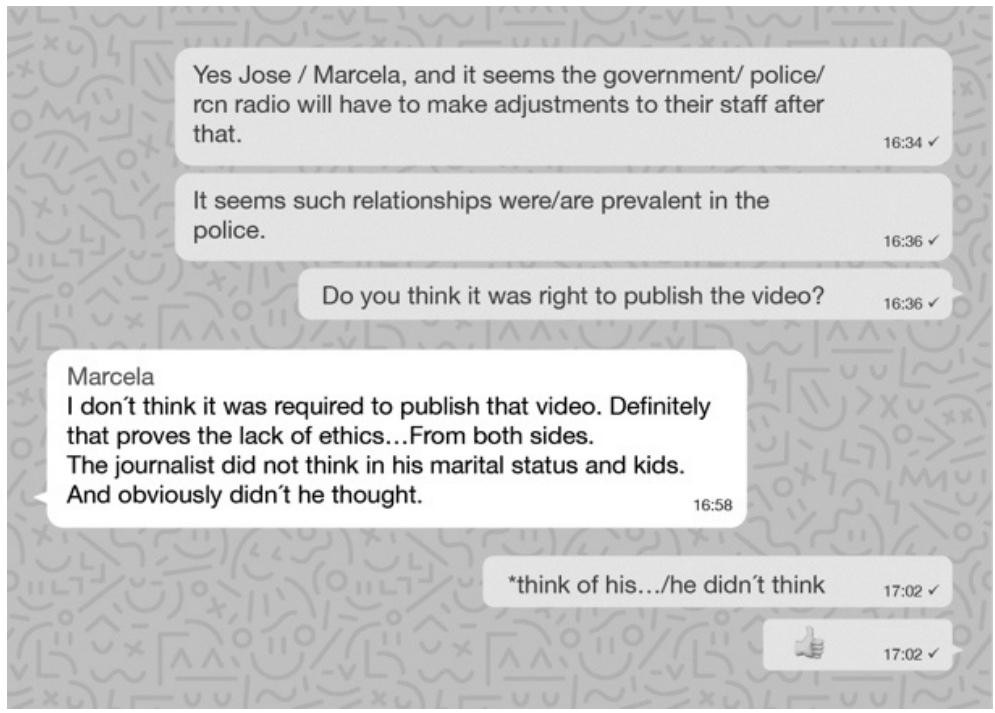

Five of the students offer not just succinct responses related to details of what had happened in Rwanda, but also thoughtful and reflective answers that explored the theme of forgiveness and drew parallels with the long running internal conflict in Colombia. 


\section{Tatiana}

The causes are firstable that the president who was in charge at that time, died and it was not clear how and why it happened and the other cause is that the tutsi were exiled from their homeland and when they attempted to come back they could not so they became a rebel group.

Figure G. Discussion on topics related to the field (2)

But read those stories people.
Stefania
Well, the UN ignored the situation basically because they did not react
properly to the fax neither the situation. That means that they were
actually aware of what was happening but they did not help and the
peacekeepers were not even trained to help or participate in the conflict
in this scenario.
Yes, the failed the country because they did not help as they were
supposed to, they just kind of ignored the situation because they had the
means to intervene and even to stop what was happening.

Figure G. Discussion on topics related to the field (3)

Mariana

I do think that the Paramilitaries are somehow related to the Tanahamwe, speaking of their procedimental characteristics, as the recruiting of young men, and the action as "self-defense civil militia", like the Paramilitaries claimed they were. Nonetheless, I don't think it is right to say that it was just "a different way of thinking" what condemned the Tutsis to be killed. Instead, they were killed just because of their physical and cultural features as Tutsis. There are studies that argue that in genocide, the argument is that there are some phenotypical characteristics that may say wether a man is a "person" or not, based for example, in the size of their nose, taking in count a definition done by "othering" a group. 
Figure G. Discussion on topics related to the field (4)

Just read the article of the NY times... it just reinforces what I said about forgiveness.

921

It's a very touching piece. Everyone should read it before class.

We will be discussing it. $922 \mathrm{v}$

Alexandra

Regarding what my classmates said, I consider that

forgiveness is a long road and each victim from their own circumstances move into the line of forgiving. In Rwanda or wherever the most significant fact, after a violent conflict is always repair victims and tell the truth. Seeking this way is possible to advance in a real reconciliation of the whole society.

\section{Rashelle}

We can stablish a parallel between the issue of forgiveness in Colombia, considering that there are many programs refer to reconciliation and the feeling of respect to others. One of them would be the search of truth, but it is never easy because there are few people willing to left those feelings of hate and anger behind.

These themes continued into the following classroom experience where the group watched a documentary on acts of genocide conducted in Indonesia during the sixties. More student contributions to the WhatsApp group (Figure H) presented opinions on the documentary in the days after viewing and although it must be noted that the teacher initiated both interactions, it was learner intersubjectivity, which helped create a rich and varied learning experience on both occasions.

One final example of the characteristics of a CoP, can be seen when learners reassure one another ahead of an in-class writing assessment (Figure I), supporting one another over a shared concern. 
Figure H. Discussion on film related to course content

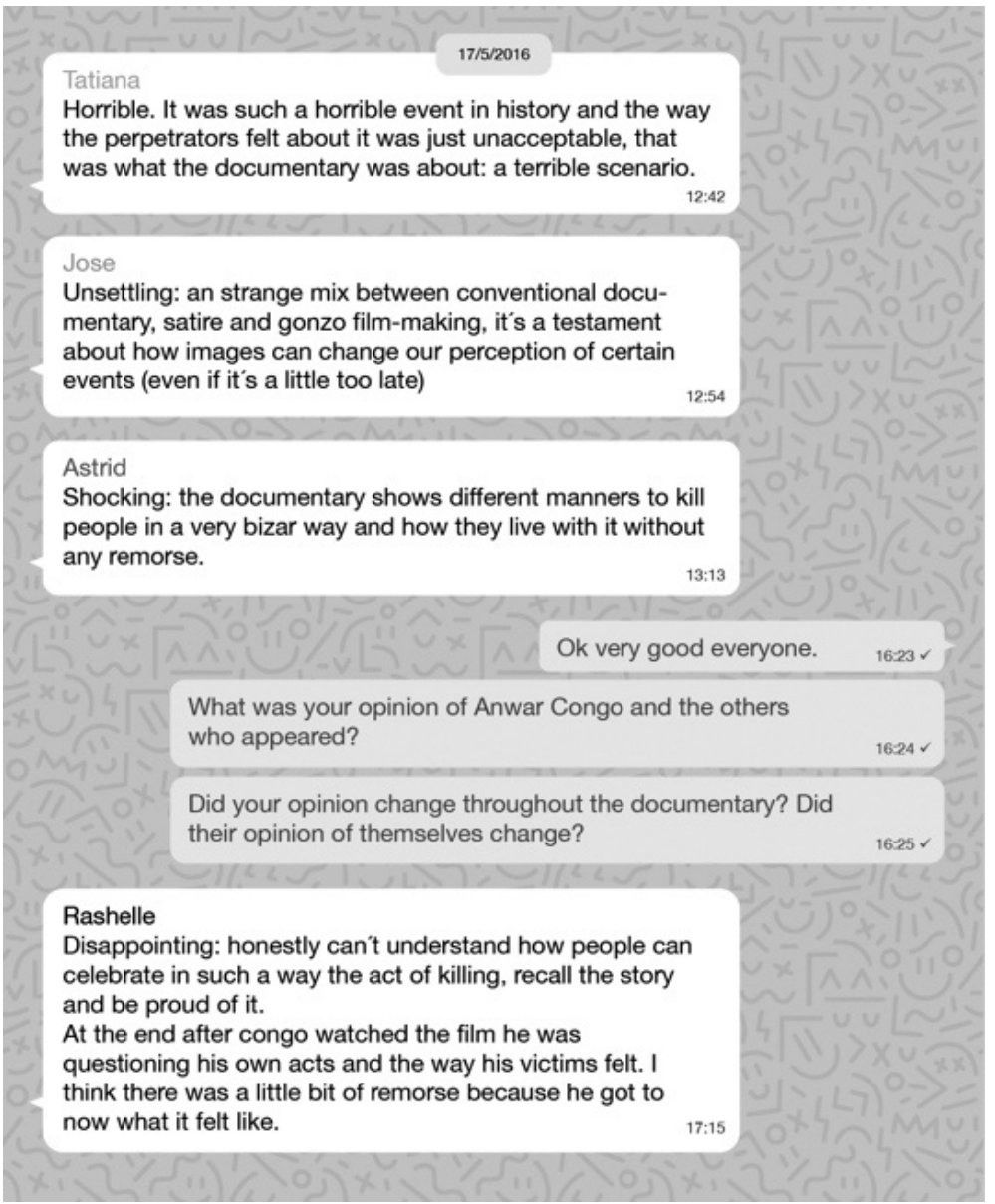

Mariana

Is anyone else worried about the writing today?

\section{Manuela \\ $\mathrm{Me}$}

Jose

But we'll be having our outlines and everything 
Figure I. Shared Concerns (2)

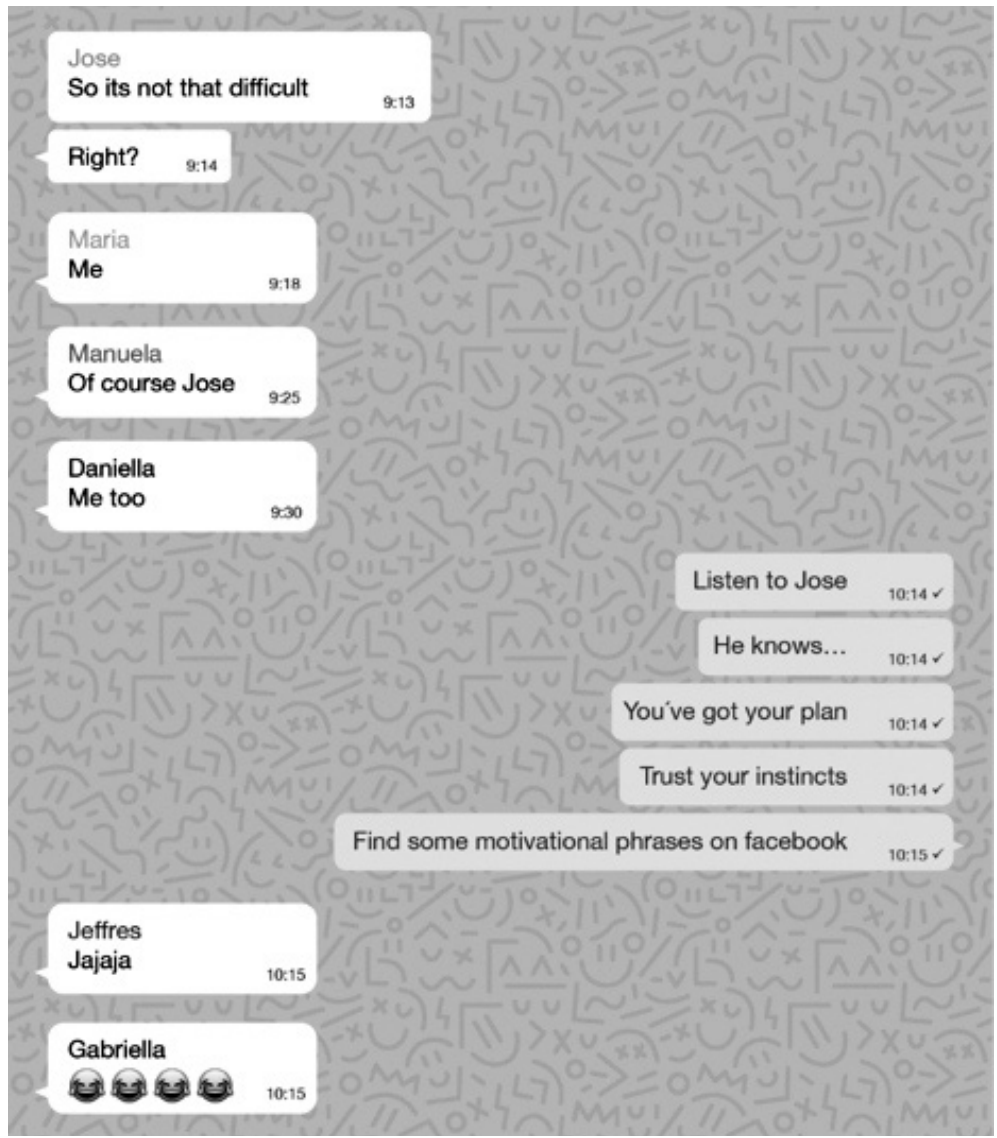

\section{Learner Reflection on the Redesign}

The reaction of the learners to the redesign was overwhelmingly positive. Some of the reflections which were posted in the group and in particular, the opinions presented in the interviews provided insight into the perception of the learners and from these activities, five dominant themes emerged. To begin, it became clear that the learners appreciated the practical nature of the WhatsApp group (Figure J). Learners commented on how they were reminded to do certain tasks and of upcoming assignments via the application and suggested that they felt they found homework tasks easier and more enjoyable to complete because of the interactional nature of such tasks within the group. 
"I loved it. Because I think that sometimes I couldn't remember the homework and then I see that you tell us remember your homework and I think "Oh my god, the homework". But I think this tool is really good because it is a new strategy to do the homework, because you do it like you're chatting with your friends and you are more interested so you remember it." Maria P

"Eh for example the links of videos or articles emmm, and all the students participate with that activities and it's very interesting and emm for example, in notebook or book, I don't make these activities and in WhatsApp yes because it's very easy, you have the internet, you have the link and eh, it's very easy

T: So you have everything at hand.

Yes, it was at hand, it was easy with the link"

Stefi

"Yes, to me there are similarities like even the assessments that we have to do in class, like we have to do the topics in the same way as in class. And differences, eh...I think it's more fun because it's WhatsApp because we are with our classmates and the teacher is there and so it feels more like (laughs) like confident like empathy.

$\mathrm{T}$ : ok so it felt more together, so it felt a little more interactive?

Yes"

Marcela

"Traditional homework is too bored compared to WhatsApp homework because when you do traditional homework, first, you can forget it. And when you do it you alone, it's too sad or boring.

T: ok, so you like doing it in the group.

Yes, if you don't know something, the others can like help you with its ideas so you can have a point of view to guide yourself"

Maria $\mathrm{P}$

"I think it's different because you use it as if you're talking to somebody else, not just that you're doing homework but you're talking to friend about something about something you must talk or something so it's kind of different because you don't feel the obligation to sit and study the topic and write something about it...

T: So it feels a little more like interaction? That helps?

Yes like interaction, and also you can respond whenever you and you don't have like a due time or something

T: Ok, so it's a little more flexible...

Yes"

Mariana 
Another theme to emerge was that of the confidence and comfort the learners felt while using the group space (Figure K). Some of the learners suggested that the written nature of the interaction within the group allowed for more thoughtful and perhaps more carefully structured participation.

Figure K. Confidence/Comfort in group

"I think in the WhatsApp group because I feel a bit more confident because in the group I'm writing it so I see if I make a mistake and if I'm talking I might eh... I'm just saying things so I might be wrong in like the time... the past or the present..."

Marcela

"Maybe the structure. I mean when you get to write in the WhatsApp group you get to structure like what you write. When you're in class you just say what you think in that moment and just say it...

T: so you put more thought into what you said in the group?

Well me, I really thought about what I wanted to say, how I wanted to say it and you get to structure more what you say..."

Mariana

"Yes it was different because it was easier and more comfortable because it's like not a traditional way but it is more comfortable like, how do you say, it's more comfortable because we are in a new era, and we use like other things and it's something good to to, not to do like traditional exercises because it's like more comfortable

T: Ok so did it feel more natural for you in that respect?

Yes it was more comfortable because of the times we are in"

Tati

Of further interest to the researcher were the opinions that suggested how the learners felt they had benefitted from seeing the posts of fellow students (Figure L). Some learners specifically referenced how they felt they had improved their knowledge of vocabulary and language structure by reading the posts of others, while some of the learners highlighted what they perceived to be the benefits of seeing the distinctive opinions of other classmates. Here it can be suggested that such examples of learner-learner scaffolding and student intersubjectivity demonstrate the potential of such a virtual community of practice. 
"Eh, yes, The em, the group em for me, well much more vocabulary than in other levels. Because all the students speaking all the topics from the class and I eh approved (sic) these discussion."

Stefi

"Mostly, I'm not sure that I read it all but most of the posts. I think it was good because it was like feedback, because of not only like me participating but other people participating so when I was participating I had the chance to see what they said, and I learned."

Tatiana

"I think I did, maybe not one or two but I think I read like every post. Well I think it's interesting to see what other people think about like, we're all talking about the same thing, like many people don't agree with what you're saying so it's interesting to read what other people are saying about the same topic. And even me for example, I don't read the news that much because I don't have time and it's a bad habit but when you posted something, it had some actuality [sic] like day to day news and it was interesting to see and also for class to contribute in class."

Mariana

"The majority. Share different opinions it's important to you because it gives you a more "amplio"?

$\mathrm{T}$ : A wider view?

Yes, a wider view"

Maria $\mathrm{P}$

"Well uh, for me I learned words that maybe I didn't. Like uh, from reading. I read a word that I don't know and I look it up. And that way I learned something new.

$\mathrm{T}$ : from what your classmates wrote?

Yeah exactly"

Marcela

Furthermore, the theme of increased participation and learner identity can be seen (Figure M), particularly in the responses of "Stefi", who stated how she felt less intimidated to contribute in the WhatsApp space than in the classroom due to the fact that, in her own words: "...nobody is seeing me". It may be argued that the group in this sense offered a greater opportunity for her to "...construct an identity as a competent and valued member" (Morita, 2004, p584) of this community. 
Figure M. Participation/ldentity within group

"It's different because in classroom, I think that so many people like how do you say "cohiver" [are reluctant] or uh... they set theirselves apart?

T: Ok, so they separate themselves...

Yes, because in class they are so shy but in WhatsApp group, they can do it"

Maria $\mathrm{P}$

"Ehmmm, I think that eh for example in the group I discussed many topics for the class. I mean emmm, for eh many factors. For example "time". It's not easy to have time to speak in class, but eh, in the group, eh yes.

T: Ok, so it gave you more opportunities?

Eh yes."

Stefi

"Yes in the WhatApp group. Eh, I am more comfortable in the WhatsApp group because I am at home and I am relaxing, an eh nobody is seeing me. $\mathrm{T}$ : Ok, and is that very important, that nobody is looking at you? So that's obviously a difference than when we're speaking in class. So does that make you feel more confident?

Yes, I eh feel more comfortable with the eh, the WhatsApp group"

"Eh, I think that I was doing in class and in the WhatsApp group but I prefer WhatsApp group, because it's easy and because I don't eh intimidate...

T: because you don't feel intimidated? Yes"

Stefi

Finally, the learner opinions suggested that they felt a greater sense of affinity as a class, because of the presence of the teacher within the group and the interactional nature of the group itself (Figure N). Some learners suggested that this heightened affinity led to a more inclusive and enriched classroom experience. 
Figure N. Affinity within group

"Yes, to me there are similarities like even the assessments that we have to do in class, like we have to do the topics in the same way as in class. And differences, eh...I think it's more fun because it's WhatsApp because we are with our classmates and the teacher is there and so it feels more like (laughs) like confident like empathy."

"Well I used to see my teachers with respect like they are like there and I'm here but with WhatsApp there's like more empathy because you like answer our questions and stuff like that."

Marcela

"I didn't have a group like that before (with the teacher involved) and it's an experience and when you do a group like that, it makes you feel so close with you, and you're not doing alone and if you are wrong, you correct us immediately and we can remember well I'm wrong on that " Maria P

"I think it was positive. I mean you were there to correct who was wrong, like with mistakes with grammar or in the tenses or whatever so I think it was good... and it also grew like a different inter...interaction with the teacher like normally many people are afraid or intimidated by the teacher and like having you in a social group, which I think it was... it was like kind of different, the dynamic was different, so when we get to the classroom we were like more comfortable to say or to speak our minds."

Mariana

"The role of the teacher is very important because eh, also interact with all the students and discuss topics that in class, eh like I said before that in class we don't have time for all the topics or the, yes, and in the group, eh in the group yes (laughs)"

Stefi

"It feels like the teacher is closer to the students. Like the course, you perceive it like more friendly and it is more...the relationship between teacher and student changes completely because of the role of the teacher in the WhatsApp group makes it more close."

Tati 


\section{Discussion}

Overall, it appears that the introduction of the WhatsApp group space was a success with this particular group. The group offered a space where learners could build upon and expand knowledge from the classroom. This extra space allowed for greater scaffolding and increased involvement for the learners and its use helped to blur the line between work and play. The group displayed various traits of communities of practice in their co-construction of knowledge, shared concerns and the passion with which they discussed key content knowledge. It must be stated, that while learners offered in-depth opinions on a range of topics both directly and indirectly linked to core content, many of these discussions were teacher initiated. Nevertheless, while the learner responses were detailed and thoughtful, there was a lack of true dialogue in respect to the manner in which they interacted with the opinions of others. Perhaps, the best conclusion from the study can be drawn from the reflections of the learners themselves, who spoke passionately about their experience within the group and how it allowed them to build rapport, knowledge and greater linguistic capability as well as helping them develop intersubjectivity and allowing greater participation. A note of caution must be sounded here though, in relation to the learner reflections. It must be stated that the positive rapport enjoyed between the learners and the teacher/ researcher may have had some influence on the responses provided. It is also important to note that not all learners offered their opinions and that some group members contributed a lot more than others over the course of the semester, meaning that while the group offered a chance for greater participation, it was not universally embraced to the same extent. On the other hand, the learners who did offer their opinions regarding the group appeared certain of the fact that the mere act of reading the contributions of others within the group aided their own learning in a variety of ways. Perhaps the potential of this passive group membership would be an interesting theme to explore in the future. With all that being said the implications of the research point towards the huge potential of applications such as WhatsApp for creating more enriching and inclusive learning experiences. 


\section{References}

Alexander, R. (2008). Towards Dialogic Teaching. York: Dialogos.

Almekhlafy, S. \& Alzuby, A. (2016). Mobile Mediated Communication: A Tool for Language Exposure in EFL Informal Learning Settings. Arab World English Journal, 7, 388-407.

Bouhnik, D. \& Deshen, M. (20I4). WhatsApp Goes to School: Mobile Instant Messaging between Teachers and Students. Journal of Information Technology Education: Research, I3, 2I7-23I.

Coffin, C. (2009) Contemporary Educational Argumentation: A Multi-Modal Perspective. Argumentation, 23, 513. https://doi.org/Io.1007/sio503oog-9i6I-Z

Coyle, D., Hood, P. \& Marsh, D. (20I0) Content and Language Integrated Learning. Cambridge: Cambridge University Press.

Crystal, D. (2003). English as a Global Language. Cambridge: Cambridge University Press.

Dalton-Puffer, C. (2007) Discourse in Content and Language Integrated Learning in CLIL Classrooms, Amsterdam: John Benjamins Publishing.

Forman, R. (2008). Using Notions of Scaffolding and Intertextuality to Understand the Bilingual Teaching of English in Thailand. Linguistics and Education, 19, 319-332.

Gutierrez, K. (2008). Developing a Sociocritical Literacy in the Third Space. Reading Research Quarterly, 43(2), 48-I64.

Hall, J. (2012), Teaching and Researching Language and Culture, Harlow: Pearson.

Lantolf, P. \& Thorne, S. (2006). Sociocultural Theory and Second Language Learning. In B. van Patten \& J. Williams (eds.), Theories in Second Language Acquisition (pp. 20I-224). Mahwah, NJ: Lawrence Erlbaum.

Lave, J. \& Wenger, E. (I99I), Situated Learning: Legitimate Peripheral Participation. Cambridge: Cambridge University Press.

Leander, K. \& Wells Rowe, D. (2006), Matching Literacy Spaces in Motion: A Rhyzomatic Analysis of a Classroom Literacy Performance. Reading Research Quarterly, 4I(4), 428-460.

Maybin, J., Mercer, N., \& Stierer, B. (1992). Scaffolding: Learning in the Classroom. In K. Norman (ed.), Thinking Voices: The Work of the National Oracy Project (pp. I86-I95). London: Hodder Arnold H\&S. 
Morita, N. (2004). Negotiating Participation and Identity in Second Language Academic Communities. Tesol Quarterly, 38(4), 573-603.

Motterman, G. \& Sharma, P. (2009). Blended Learning in a 2.0 World. International Journal of Emerging Technologies \& Society, 7(2), 83-96.

Norton, B. (2000). Identity and Language Learning: Gender, Ethnicity and Educational Change. Harlow: Pearson.

Vygotsky, L. S. (I978). Interaction between learning and development. In M. Cole, V. John-Steiner, S. Scribner, \& E. Souberman (eds.), Mind in Society: The development of higher psychological processes (pp. 79-9I). Boston: Harvard University Press.

Wenger, E., McDermott, R.A. \& Snyder, W. (2002) Cultivating Communities of Practice: A Guide to Managing Knowledge. Boston: Harvard Business School Press. 